\title{
A INFLUÊNCIA DOS POTENTADOS LOCAIS NA ESTRUTURA ADMINISTRATIVA BRASILEIRA
}

\author{
THE INFLUENCE OF LOCAL POTENTATES ON THE BRAZILIAN \\ ADMINISTRATIVE STRUCTURE
}

\section{LA INFLUENCIA DE LOS POTENTADOS LOCALES EN LA ESTRUCTURA ADMINISTRATIVA BRASILEÑA}

Vinícius Tadeu Vieira Campelo dos Santos ${ }^{1}$

\section{Resumo}

A historiografia brasileira sempre abordou a questão da relação entre o poder público e o poder privado na construção do Estado brasileiro. Com diferentes modos de análises e de argumentação, diversos foram os autores que partilharam da visão de que, a formação do Estado brasileiro desde o seu período colonial teve como característica principal a centralização administrativa, dificultando assim, a participação e a influência de grupos locais nas diretrizes estatais. Partindo para outra perspectiva, dispomos de análises onde a principal fonte de raciocínio foi o domínio exacerbado dos potentados locais na ordem pública, impedindo assim, a realização de um Estado dito como racional legal. Nessa linha de análise, o Estado brasileiro seria fraco e incipiente, se comparado aos grupos locais estabelecidos no país desde o período colonial, aonde esses potentados locais colocariam os interesses privados a frente do interesse público. Tais considerações serão analisadas no presente artigo, visando assim, contribuir para os estudos acerca da manifestação do poder público e privado no decorrer da história brasileira.

Palavras-chave: Brasil; Público; Privado.

\section{Abstract}

Brazilian historiography has always addressed the question of the relationship between the public power and the private power in the construction of the Brazilian state. With different modes of analysis and argumentation, several were the authors who shared the view that, the formation of the Brazilian state since its colonial period had as main characteristic the administrative centralization, thus hindering the Participation and influence of local groups in the state guidelines. Starting from another perspective, we have analyses where the main source of reasoning was the exacerbated dominance of local potentates in public order, thus preventing the realization of a state that was said to be legal rational. In this line of analysis, the Brazilian state would be weak and incipient, compared to the local groups established in the country since the colonial period, where these local potentates would put private interests ahead of the public interest. These considerations will be analyzed in this article, aiming to contribute to the studies about the manifestation of public and private power in the course of Brazilian history.

Keywords: Brazil; Public; Private.

\section{Resumen}

La historiografía brasileña siempre ha abordado la cuestión de la relación entre el poder público y el poder privado en la construcción del Estado brasileño. Con diferentes modos de análisis y argumentación, varios fueron los autores que compartieron la opinión de que, la formación del Estado brasileño desde su período colonial tenía como característica principal la centralización administrativa, obstaculizando así la Participación e influencia de los grupos locales en las directrices estatales. Desde otra perspectiva, tenemos

\footnotetext{
${ }^{1}$ E-mail: campelo.viniciust@gmail.com
} 
análisis donde la principal fuente de razonamiento fue el exacerbado dominio de los potentados locales en el orden público, impidiendo así la realización de un estado que se decía que era racional desde el punto de vista jurídico. En esta línea de análisis, el Estado brasileño sería débil e incipiente, en comparación con los grupos locales establecidos en el país desde el período colonial, donde estos potentados locales pondrían los intereses privados por delante del interés público. Estas consideraciones serán analizadas en este artículo, con el objetivo de contribuir a los estudios sobre la manifestación del poder público y privado en el curso de la historia brasileña.

Palabras-clave: Estado; Brasil; Público; Privado.

\section{INTRODUÇÃO}

Os estudos referentes a associação entre o poder público e poder privado no Brasil se tornou ponto chave para explicar as relações políticas e sociais do país. De acordo Vellasco (2009) existem três eixos explicativos para demonstrar a influência privada e pública no pensamento social brasileiro. O primeiro tange a uma estrutura social que se estabeleceu no país devido ao modo de colonização aqui empregado. A segunda vertente traz como característica uma transposição do aparato de dominação herdado de Portugal, porém sem uma adaptação a realidade brasileira. $\mathrm{O}$ terceiro modelo é explicado através da imbricação entre a formação social específica com a herança ibérica estabelecida.

Os primeiros autores dessa dicotomia entre o poder privado versus poder público, iniciaram os seus estudos na década de 1920 a 1940, destaque para Nestor Duarte (1939) e Oliveira Viana (1920). Em seus trabalhos há a identificação de que a estrutura social brasileira seria "feudalizada", ou seja, descentralizada, ocasionando assim na criação de um Estado incapaz de oferecer resistência frente aos potentados rurais. Segundo Vellasco "Em ambas a impossibilidade de um Estado que se afirme sobre o conjunto de território e quebre os domínios locais do patriarcado rural, o que torna aqueles que vivem na base do sistema, escravos, agregados, inteiramente dependentes, clientela do patronus local" (VELLASCO, 2009, p. 76).

Conforme a interpretação de Oliveira Viana, os indivíduos pertencentes a essa sociedade brasileira, orlam em uma esfera de dependência pessoal e econômica do chefe local, onde "só estão garantidos, seguros defendidos, quando tem para ampará-los o braço passante de um caudilho local" (VIANA, 1920, p. 1049). Com isso, não houve a efetivação de uma ordem liberal legal no Brasil, em decorrência do poder exacerbado dos potentados rurais. Seguindo com o seu raciocínio, Oliveira Viana argumentou que no Brasil seria necessário a formação de um Estado centralizado com viés autoritário, capaz de fazer frente aos grupos locais, delimitando assim, as áreas de influência e de efetivação do espaço público.

Nestor Duarte (1939) partiu do mesmo princípio de Oliveira Viana. Em sua reflexão, Nestor Duarte acrescentou que a influência do poder da Igreja Católica possibilitou um enfraquecimento da autoridade política em Portugal o que culminou também na debilidade das instituições brasileiras no decorrer do processo de formação do Brasil. Outro ponto de argumentação na tese de Nestor Duarte foi a influência do poder familiar na ordem política portuguesa. Assim como a Igreja Católica, a ordem familiar não possibilitou uma espécie de afastamento do Estado no seio familiar, pois esse último, não teria capacidade de influência na esfera privada. A organização de característica familiar, peculiar ao Estado português, foi transferida para a colônia, onde se 


\section{A influência dos potentados locais na estrutura administrativa brasileira}

fortaleceu. Esse fortalecimento do âmbito familiar como centro econômico e político, fez com que o Estado se tornasse um elemento secundário as famílias. Diferentemente do seu contemporâneo Oliveira Viana, Nestor Duarte não relacionou o fortalecimento estatal com o estabelecimento de um Estado autoritário, pois era defensor de um Estado democrático de direito.

O segundo ponto de reflexão recaiu sobre as discussões com respeito ao patrimonialismo como característica central do Estado brasileiro. Raymundo Faoro (2000) em seu eixo de argumentação, considerou que o Estado patrimonial português ao ser transplantado à colônia e reproduzido com as mesmas características, acarretou como consequência, a pouca influência dos grupos locais nas diretrizes estatais, ficando alheios ao Estado, prejudicando assim a organização de uma sociedade civil.

Em sua argumentação, Raymundo Faoro, discorreu sobre a existência de um estamento dentro da burocracia do Estado patrimonial. Esse estamento conforme ao seu pensamento difere de classe social, pois é apenas uma camada que age na economia. O jurista fez uma análise de longa duração, percorrendo os períodos desde a formação do Estado português no século XIV, perpassando pelo período colonial culminando com a formação do Estado brasileiro. Mudanças ocorridas tanto na implantação da República, como na Revolução de 1930, não foram capazes de romper com o estamento burocrático brasileiro, proveniente desde o período colonial. O termo "burocracia" é usado por Faoro como: "apropriação do cargo - o cargo carregado de poder próprio, articulado, com o príncipe, sem a anulação da esfera própria de competência” (FAORO, 2000, p. 95). Logo o uso da expressão "burocracia" não conota o sentido moderno weberiano, ligado ao aparelho racional.

Esse estamento burocrático restringiu-se à uma camada social excludente, que não representava os anseios da nação. O capitalismo estabelecido no Brasil, de acordo com o autor, teve como característica ter sido politicamente orientado. A tese de Faoro sofreu críticas pois não propôs nenhuma mudança com a finalidade de alterar com essa lógica do Estado patrimonial. De acordo com Simon Schawartzman “A principal crítica que se pode fazer a Faoro é a sua tendência de atribuir ao patrimonialismo político brasileiro um caráter absoluto e imutável do tempo" (SCHAWARTZMAN, 1982, p. 82).

O terceiro modelo de reflexão têm como característica ser de uma vertente mais interpretativa. A herança ibérica agregada com valores sociais, se tornaram ingredientes para a formação de uma cultura patriarcal, na qual, os vínculos pessoais acabam por adentrar nas instituições de um Estado Moderno.

Sergio Buarque de Holanda em Raízes do Brasil deixou explicito que o Estado formado no Brasil foi marcado por uma "invasão do público pelo privado, do Estado pela família" (HOLANDA, 1999, p. 50). As relações existentes na esfera privada continuariam no âmago da esfera estatal, fazendo com que os mecanismos de impessoalidade não estivessem presentes. O cidadão brasileiro de acordo com Buarque de Holanda seria marcado pela cordialidade. Essas são características que segundo ao autor demonstram a incapacidade da consumação de uma cidadania plena.

Com uma interpretação mais dual sobre a formação do Estado brasileiro. Fernando Uricoechea (1978) utilizou o termo burocracia patrimonial. Conforme desenvolveu o seu estudo, o autor concebeu a existência de um dispositivo administrativo burocrático ordenado pelo Estado, assim como um dispositivo administrativo conferido patrimonialmente por potentados locais. Nessa interligação de dispositivo houve uma espécie de 


\section{A influência dos potentados locais na estrutura administrativa brasileira}

construção hibrida da ordem. ${ }^{2}$ Assim como um Minotauro, o Estado brasileiro era administrado tanto por aspectos públicos como por aspectos privados, assumindo compromissos com as elites locais, tendo em vista a consolidação estatal.

Portanto, o ponto de inflexão sobre a relação entre o poder público com o poder privado no Brasil é exposto sob diferentes interpretações. Na medida em que as instituições pertencentes ao Estado nacional se desenvolveram, a esfera pública foi se ampliando, e a influência de interesses privados foi se limitando gradativamente.

\section{O PRIVADO NA ADMINISTRAÇÃO BRASILEIRA}

O poder privado no Brasil teve como característica ter se adentrado nas localidades. No período colonial, a influência dos potentados locais na administração era por meio da Câmaras Municipais. Com uma infinidade de atribuições, as autoridades municipais eram legitimadas através de eleições, geralmente organizadas, a cada três anos. Nas eleições, o eleitorado era restrito aos "homens bons". Eram escolhidos entre os "homens bons" três a quatro vereadores, escrivão, tesoureiro e também um procurador. Essas autoridades eram responsáveis por todas as decisões de ordem local, tanto de caráter administrativo como policial.

Na historiografia há diferentes interpretações sobre o poder das Câmaras no período colonial. Gilberto Freyre (2006), conferiu as Câmaras municipais como um prolongamento do poder do patriarcado rural. Sua análise partiu do princípio de que a tarefa de colonizar o território brasileiros, ficou sob tutela familiar e não pelo Estado. A influência do patriarca rural em sua localidade era enorme, se legitimando por intermédio das Câmaras por ser uma instituição de caráter oficial. Com o controle sobre as Câmaras os potentados locais projetavam a sua autoridade sobre a sociedade. (FREYRE, 2006). Nesse quesito a autoridade central ficava em segundo plano na esfera local. A interpretação feita por Vitor Nunes Leal se aproxima com a de Gilberto Freyre nessa questão. Nunes Leal discorreu que devido a debilidade burocrática, o rei se tornou impotente na tentativa de enfraquecer o mandonismo dos potentados nas Câmaras.

Não seria, pois, de estranhar que no período aludido de dominação quase exclusiva do senhoriato fundiário, tivessem as câmaras municipais - instrumento do seu poder na ordem política - uma larga esfera de atribuições, que resultava muito menos da lei do que da vida. (LEAL, 1975, p. 66).

De acordo com o Raymundo Faoro a autonomia concedida a Câmara municipal ocorreu durante um breve momento. Para Faoro "a metrópole confiou a colonização ao morador e ao senhor de engenho, em compromisso de que logo se arrependeu, temerosa das consequências autonomistas e descentralizadoras" (FAORO, 2000, p. 210). A Câmara municipal na visão desse autor serviu apenas como um mecanismo auxiliar na execução do poder metropolitano.

Caio Prado Júnior (1997) argumentou que a Câmara municipal foi uma instituição importante no período colonial brasileiro. Os cargos que a compunham eram elegíveis, e no ponto de vista deste autor, isso

\footnotetext{
${ }^{2}$ De acordo com Fernando Uricoechea no Brasil Imperial havia uma articulação de princípios opostos, ou seja, a autoridade tradicional, proveniente das elites agrárias e uma autoridade racional proveniente dos estratos do governo imperial in: (URICOECHEA,1978)
} 


\section{A influência dos potentados locais na estrutura administrativa brasileira}

permitiu um elo entre o povo e as autoridades gerais. A sua importância foi demonstrada após a decadência das instituições coloniais "será o único órgão da administração que na derrocada geral das instituições coloniais, sobreviverá com todo o seu poder, quiçá engrandecido" (PRADO JÙNIOR, 1997, p. 319). Portanto esse excesso de poder direcionado as Câmaras no decorrer do período colonial, foi colocado por parte da historiografia, como uma consequência direta do distanciamento do poder régio.

A autora Maria Beatriz Nizza da Silva (1986) apresentou as diferentes atribuições concedidas as Câmaras, ressaltando a autonomia da instituição.

Vereadores, escolhidos entre os homens bons locais, alcaides, juizes ordinários, procuradores e almotacés constituíam o governo das vilas, formando o Senado da Câmara e deliberando sobre abastecimento, segurança, práticas de ofícios, emprego de pesos e medidas, limpeza e conservação urbanas, multas e circulação, tendo também algumas atribuições judiciárias e militares locais. Os membros das Câmaras gozavam de importantes privilégios, entre eles o de não poderem ser presos sem expressa ordem régia. Tinham autoridade para convocar as chamadas juntas Gerais em tempos especiais de agitação política ou social, às quais se obrigavam a comparecer as autoridades executivas, judiciárias, financeiras e militares. Além disso, possuíam relativa autonomia financeira, em razão dos tributos forais, e exploravam os seus respectivos rossios, destinados a postos públicos ou ao aproveitamento que lhes conviesse dar. (SILVA, 1986, p. 280)

Conforme o excerto acima, a circunstância de possuírem tantas prerrogativas, contribuiu para uma autonomia municipal em relação ao governo metropolitano. Portanto, as relações de poder estabelecidas no interior da colônia eram ditadas pelas autoridades municipais, fazendo com que ordens exclusivamente metropolitanas tivessem uma influência circunstancial no interior colonial.

Essa estrutura de poder das Câmaras passou a se modificar com a vinda da família real ao Brasil em 1808. Sergio Buarque de Holanda (1970) expõe que após a Independência do Brasil em 1882, se iniciou um movimento de enfraquecimento das Câmaras, visando o fortalecimento estatal e uma maior centralização administrativa. Em 1828 as Câmaras foram declaradas corporações meramente administrativas, devido a uma modificação na legislação que fora alterada com a Lei de $1^{\circ}$ de Outubro de $1828 .^{3}$ Essa nova legislação foi elaborada em um período de centralização administrativa. Determinadas funções das Câmaras foram eliminadas, limitando o poder de atuação da corporação. As Câmaras municipais ficaram subalternas: aos conselhos gerais, pelos presidentes das províncias e pelo Governo Geral.

No período das Regências (1831-1840), principalmente após a criação do Ato Adicional de 1834 que intercedeu a favor da descentralização do poder, houve uma redução maior do poder municipal, em favor de um acréscimo do poder provincial. Entre as medidas estabelecidas, a criação da Assembleias provinciais salientou ainda mais a perda do poder das referidas instituições. De acordo com Maria de Fátima Gouvêa (2008) as Câmaras após a emenda de 12 de agosto de 1834 "tinham permissão apenas para mandar petições para o governo provincial sobre as necessidades de seus municípios e informações para a confecção dos orçamentos das câmaras" (GOUVÊA, 2008, p. 113). Outra autora que se aproxima na linha de pensamento de

\footnotetext{
${ }^{3}$ LEI DE $1^{\circ}$ de outubro de 1828 - Criando em cada Cidade e Vila do Império Câmaras Municipais. In: CONSTITIÇÕES
} DO BRASIL. Vol. I. Brasília: Senado Federal, 1986. 


\section{A influência dos potentados locais na estrutura administrativa brasileira}

Maria de Fátima Gouvêa no tocante Câmara Municipal é Miriam Dolhnikoff (2005). Em sua obra O pacto imperial, a autora argumenta que nas Câmaras Municipais circularia apenas uma elite local subordinada ao governo provincial. As autoridades locais (vereadores, por exemplo), não corresponderiam a uma elite nacional. Sustentando a tese de que a formação do Estado Nacional brasileiro ocorreu devido a uma articulação de diferentes elites regionais. Essas elites regionais eram elites políticas, pois circundavam o cenário político provincial como o nacional (DOLHNIKOFF, 2005).

Consideradas um entrave para a efetivação do governo central, tanto na esfera local quanto provincial, as Câmaras foram cerceadas durante o Império brasileiro, como argumentou Juliana Teixeira Souza:

$\mathrm{Na}$ medida em que os responsáveis pela direção do Estado imperial percebem a inconveniência do antigo modelo administrativo e distribuição de poderes com respeito aos seus interesses, as câmaras deixam de ser identificadas como representantes do "povo", passando a ser reconhecidas como canais de expressão das paixões desmedidas e das ambições particulares. Então se difunde o argumento de que, governadas por suas próprias vontades, elas seriam incapazes de assegurar uma administração eficiente e útil (SOUZA, 2011, p. 5).

Os recursos municipais no período imperial eram escassos, isso facilitava na dependência das câmaras em relação à Assembleia Provincial. O enfraquecimento se ampliou no decorrer do século XIX. Por fim, uma das últimas responsabilidades da instituição era a manutenção da salubridade dos municípios, construção de obras públicas (pontes, fontes, cemitérios, estradas, etc), solução de conflitos locais e uma participação direta no processo eleitoral, na contagem dos votos. ${ }^{4}$

A atenuação do poder municipal continuou com o advento da República. Com a promulgação da Constituição de 1891, houve a liberdade do Estado para regular a administração municipal. O poder tributário dos municípios era derivado do poder estadual, acarretando em uma fraqueza financeira dos municípios. Em consequência disso, um fenômeno recorrentemente exposto em diversas obras da literatura brasileira se tornou comum durante a Primeira República, o coronelismo.

\section{O CORONELISMO}

A obra de Victor Nunes Leal, Coronelismo, Enxada e Voto teve sua primeira edição em 1949, proveniente da tese $O$ Município e o Regime Representativo no Brasil - Contribuição ao Estudo do Coronelismo.

Em seu livro, o autor procurou delimitar as relações de poder entre o governo municipal, estadual e federal. Seu foco estava sobre o sistema ali empregado. O próprio Victor Nunes Leal delimita isso:

O que procurei examinar foi sobretudo o sistema. O coronel entrou na análise por ser parte do sistema, mas o que mais me preocupava era o sistema, a estrutura e a maneira pelas quais as relações de poder se desenvolviam na Primeira República, a partir do município (LEAL, 1980, p. 13).

\footnotetext{
${ }^{4}$ Decreto ${ }^{\circ}$ 842, de 19 de Setembro de 1855. In. Coleção das Leis do Brazil. Disponível no site da Câmara dos Deputados: $\quad$ http://www2.camara.leg.br/legin/fed/decret/1824-1899/decreto-842-19-setembro-1855558297publicacaooriginal-79444-pl.html) Acesso em 21 de fevereiro de 2018.
} 


\section{A influência dos potentados locais na estrutura administrativa brasileira}

O termo coronel é diretamente relacionado com a criação da Guarda Nacional em 1831, sendo que, a sua proliferação ocorreu principalmente em famílias de origem latifundiárias. O título coronel não tinha uma importância muito grande quando colocado em comparação com categorias de nobreza como: duque, marquês, conde, visconde e barão. Títulos acadêmicos como bacharel e doutor, conferiam mais prestígio que o termo "coronel". Em termos gerais "o título de coronel tornou-se um título inferior, com a conotação de novo-rico ou até mesmo de vulgaridade. Tal distinção de classe acentuou-se ainda mais no final do século XIX" (PANG, 1979, p. 26). A nomeação de títulos na época Imperial seguia questões partidárias. Esses títulos concedidos aos potentados locais, serviam como instrumento de dominação da política local. "Socialmente coronel, tornou-se sinônimo de chefe político; as pessoas preferiam ser chamadas de coronel, em vez de "senhor", uma designação mais mundana" (PANG, 1979, p. 30).

O fenômeno do coronelismo é datado para Leal, tem o seu auge no período da Primeira República (1889-1930), sendo uma consequência da convergência de fatores políticos como econômicos. O aspecto político é resultado do Constituição de 1891 que implantou o federalismo. Foi por meio desse federalismo que as oligarquias regionais procuravam compor forças junto com o governo estadual e federal.

Para José Murilo de Carvalho:

$\mathrm{O}$ federalismo criou um novo ator político com amplos poderes, o governador de estado. $\mathrm{O}$ antigo presidente de Província, durante o Império, era um homem de confiança do Ministério, não tinha poder próprio, podia a qualquer momento ser removido [...]O governador republicano, ao contrário, era eleito pelas máquinas dos partidos únicos estaduais, era o chefe da política estadual. Em torno dele se arregimentavam as oligarquias locais, das quais os coronéis eram os principais representantes. Seu poder consolidou-se após a política dos estados implantada por Campos Sales em 1898, quando este decidiu apoiar os candidatos eleitos "pela política dominante no respectivo estado (CARVALHO, 1997).

Com relação à circunstância econômica, o coronelismo na concepção de Leal trata-se da decadência do poder dos fazendeiros. Esse enfraquecimento econômico provocou uma atenuação do poder político dos coronéis, tanto em relação a sua clientela quanto aos seus rivais. Portanto o autor define coronelismo como "Uma forma peculiar de manifestação de todo o poder privado, ou seja, uma adaptação em virtude da qual os resíduos do nosso antigo exorbitante poder privado têm conseguido coexistir com um regime político de extensa base representativa" (LEAL, 1975, p. 20).

O coronelismo tem algumas características bem especificas, como mandonismo, filhotismo e o falseamento do voto. Todos esses elementos, em conjunto, são necessários para que o coronelismo se sustente. O conceito de coronelismo funde-se com mandonismo. O mandonismo é apresentado por José Murilo de Carvalho como:

O mandão, o potentado, o chefe, ou mesmo o coronel como indivíduo, é aquele que, em função do controle de algum recurso estratégico, em geral a posse da terra, exerce sobre a população um domínio pessoal e arbitrário que a impede de ter livre acesso ao mercado e à sociedade política (CARVALHO, 1997).

O mandonismo esteve presente no Brasil desde o período colonial. Não pode ser considerado uma forma de sistema político, se encaixa mais como uma característica da política tradicional. O mandonismo se ampliou no interior, pois a população rural de determinada maneira foi abandonada pelo poder público 


\section{A influência dos potentados locais na estrutura administrativa brasileira}

(JANOTTI, 1992) ficando sob tutela dos chefes locais. A autora Maria de Lourdes Janotti argumentou que o chefe local, o mandão, era visto pela comunidade rural como um protetor natural, devido à grande influência que exercia sobre os seus potentados ao longo de gerações.

Solidamente enraizada na proteção e na lealdade, a sociedade rural repousava na troca de favores, de homem para homem. O coronel oferecia proteção exigia irrestrita adesão. Em algumas localidades isoladas, o chefe comportava-se como um pequeno senhor feudal, chegando alguns a ter força armada e até cunhar a própria moeda (JANOTTI, 1992, p. 57).

O coronelismo é um momento da história onde os “mandões" não tem a mesma força e influência na comunidade local como anteriormente.

O fenômeno do filhotismo foi amplamente difundido. O termo associado a questão familiar, sendo que a família ou clã era composto tanto por indivíduos consanguíneos, como por agregados. Nesses termos, a família: "incluía a família em si, pessoas da mesma linhagem, parentes por afinidade, afilhados de batismo ou de casamento e, às vezes, o povo depende do ponto de vista socioeconômico" (PANG, 1979, p. 40). O filhotismo tinha como característica um favorecimento de parentes, consequentemente uma transferência de poder para o novo membro do clã. O intuito é manter a legitimidade, fazendo com que a "família" do coronel conservasse tanto os seus interesses políticos como os econômicos.

A respeito do falseamento dos votos haviam várias práticas recorrentes no processo eleitoral. Após o fim do voto censitário estabelecido pelo Império, qualquer cidadão homem, maior de 21 anos tinha direito ao voto. Nesse primeiro momento da República, tanto mulheres como analfabetos e mendigos não tinham direito ao voto. A maioria da população eleitoral se encontrava no campo. Nas áreas rurais, os homens livres normalmente pequenos proprietários de terra, possuíam algum tipo de relação de compadrio com o coronel local.

A apuração das eleições ficava sob tutela das mesas eleitorais, tornando-se verdadeiras farsas. O sistema era organizado em três comissões com a finalidade de fomentar as eleições "uma comissão de registro (junta de alistamento), uma comissão eleitoral executiva (junta ou mesa eleitoral), e uma comissão de apuração (junta de apuração" (PANG, 1979, p. 34). As três juntas eram formadas por um juiz municipal, um juiz da comarca (juiz de direito) designado pelo próprio governador estadual e membros escolhidos pelo eleitorado local. Esse tipo de organização facilitava a manipulação da eleição por parte do grupo dominante local. Além desse mecanismo a violência era uma prática comum nos períodos de eleição.

Como forma de evitar com que fossem registrados eleitores que haviam declarado apoio ao candidato rival, o uso de capangas armados, denominados em alguns locais do país como jagunços, serviu como ferramenta de intimidação dos eleitores. Conforme os votos fossem apurados, a junta revisora conferia os resultados e concedia (diplomas) para os candidatos, explicitando os votos que cada candidato obteve. Outra forma de causar perturbação no processo eleitoral se fazia por meio do afastamento do juiz da sede/comarca. Ao comunicar o afastamento, um suplente era escolhido pelo governador, com o aval dos coronéis locais. O autor, Eu - Soo Pang argumenta em seu livro Coronelismo e Oligarquias 1889-1934 que "frequentemente 


\section{A influência dos potentados locais na estrutura administrativa brasileira}

eleições eram canceladas por violentos confrontos; ás vezes, o coronel dominante guardava o registro em sua casa, aberto apenas aos que apoiavam" (PANG, 1979, p. 35).

Na proporção que artimanhas eleitorais não conseguissem atingir o efeito desejado, novos artifícios foram criados. O principal exemplo 'disso é a falsificação denominada bico de pena. O bico de pena consistia em inventar nomes, pessoas falecidas tinham os nomes colocados na lista de eleitores e os ausentes compareciam na votação. Essa forma como as eleições eram conduzidas, só se alterou com a aprovação do Decreto $n^{\circ} 21076^{5}$ de 24/02/1932. Este decreto previa que a apuração dos votos e o reconhecimento dos respectivos candidatos eleitos tornava-se tarefa da justiça eleitoral, não mais das autoridades municipais.

Vale salientar que as fraudes eleitorais, além de garantirem a vitória do grupo da situação local, também tinham como função coagir os eleitores. Com as sucessivas eleições, o voto acabou por se tornar cada vez mais valorizado. O eleitor "começa a descobrir-se exigido, solicitado, descobre o poder de barganha que possui. Passa a pedir, a exigir" (VILAÇA, 1978, p. 39). O votante nesse momento se tornou parte do sistema. Reconhecendo a sua importância no jogo eleitoral, o eleitor passou a exigir mercadorias, roupas, alimentos, empregos e até mesmo dinheiro. Coube aos coronéis aceitarem esse novo posicionamento dos eleitores. Consequentemente, o processo eleitoral acabou por ficar mais oneroso para o coronel. Essa exigência por parte do eleitor, ressalta o enfraquecimento do coronel. Antes soberano em seu potentado, ele passou a ser apenas um intermediário no processo eleitoral.

Por meio dessas características que o coronelismo se manteve por determinado período. A relação de troca entre as esferas municipal, estadual e federal é de extrema importância para a organização do sistema coronelista.

E assim nos aparece um aspecto importantíssimo do 'coronelismo' que é o sistema de reciprocidade: de um lado, os chefes municipais e os 'coronéis' que conduzem os eleitores como quem toca tropa de burros; de outro lado, a situação política dominante no Estado, que dispõe do erário, dos empregos, dos favores e da força policial, que possui, em suma, o cofre das graças e o poder da desgraça (LEAL, 1975, p. 43).

Caso não houvesse esse sistema de reciprocidade a autoridade do coronel seria diminuída. Nessa relação o poder decadente era proveniente do coronel, sob consequência da fraqueza dos municípios. No período republicano houve uma expansão do poder público estadual, contudo, isso não resultou em um retraimento do poder privado local. Esses poderes não são excludentes, exemplo disso foi o Estado colocar sob tutela do chefe situacionista local a força policial. Normalmente o "chefe municipal" era ligado ao governante estadual. $\mathrm{O}$ apoio ao governo estadual era visando um amparo e garantia de favores. Os políticos estaduais almejando manter sua base de apoio nos municípios interioranos, concediam um poder extralegal aos chefes municipais. Essa autonomia tinha como princípio um acordo, onde o governo estadual permitia isso aos seus aliados locais, pretendendo que os mesmos cumprissem o seu dever coronelista. Normalmente as atitudes dos coronéis eram de cunho conservador, como forma de garantir e continuar com sua rede de proteção, o coronel:

\footnotetext{
${ }^{5}$ BRASIL - Decreto de 24 de fevereiro de 1932. Código Eleitoral. Biblioteca da Câmara dos Deputados. Brasília DF. Disponivel em:< http://www2.camara.leg.br/legin/fed/decret/1930-1939/decreto-21076-24-fevereiro-1932-507583publicacaooriginal-1-pe.html> Acesso em 02/02/2018.
} 
Promove a urbanização em detrimento de suas bases rurais; ou patrocina aberturas de estradas para as capitais, facilitando a penetração do elemento moderno perturbador de sua hegemonia. Para sobreviver como poder econômico em estrutura que se diversifica, de senhor de terras passa a comerciante, e até mesmo em empreendedor industrial... para alargar a base eleitoral - fonte de sua nova força, decorrente do poder estranho do Estado, mas que ele incorpora - abre escolas e fabrica eleitores, origem de um processo incipiente de politização que fatalmente lhe substituirá no mando (VILAÇA, 1978, p. 19).

Na medida em que a modernidade avançou sobre o interior brasileiro, o fenômeno do coronelismo teve que se adaptar à nova realidade. A pressuposição de que todos os coronéis são detentores de terras foi difundida pela literatura com obras José Lins do Rego ${ }^{6}$, Jorge Amado ${ }^{7}$, Dias Gomes ${ }^{8}$ entre outros. Para um coronel obter êxito são necessários fatores externos, como sua profissão, recursos pessoais e não exclusivamente a questão da posse de terras.

O coronel proprietário de terras foi o tipo mais comum. O autor Eul - Soo Pang, destacou as diferenças entre o coronel proprietário de terras do interior, com o proprietário de terras do litoral, como forma de demonstrar que não havia um modelo homogêneo com relação aos coronéis. Essas distinções são destacadas principalmente na relação de dependência desses coronéis com o governo estadual e também no uso da violência em suas áreas de dominação. Segundo ao autor.

Municípios litorâneos, tais como Ilhéus e Santo Amaro, na Bahia, eram firmemente ligados à economia nacional e internacional. Consequentemente os coronéis dessas regiões eram mais sujeitos ao controle do Estado. O inverso é verdadeiro quanto ao coronel do interior, para quem a violência - e não o arbítrio do Estado - tornou-se o instrumento chave para a solução dos conflitos. (PANG, 1979, p. 57).

Com o crescimento comercial no período da Primeira República, os comerciantes passaram a ter tanta influência política assim como, os proprietários de terras. Despontou nesse período uma nova modalidade de coronel, o coronel comerciante. Em cidades nordestinas como Juazeiro e Feira de Santana, na Bahia, o controle da política local ficou sob tutela dos comerciantes. O regime dos coronéis não existiu somente nos municípios do interior do Brasil, haviam coronéis em cidades onde o número de eleitores era elevado. Como forma de garantir a maioria dos votos para os representantes da situação estatal, temos a figura do coronel chefe ou curral distrito. Normalmente os chefes do curral distrito eram indivíduos de diversas camadas sociais e tinham

\footnotetext{
${ }^{6}$ José Lins do Rego (1901-1957) foi um escritor brasileiro nascido na Paraíba. Nasceu no engenho, filho de tradicional família da oligarquia açucareira do Nordeste. É atribuído ao autor a invenção do romance moderno brasileiro, e suas obras são um marco na literatura regionalista. Autor dos romances "Menino do Engenho", "Doidinho", "Banguê", "Riacho Doce", "Fogo Morto" entre outras. Foi eleito membro da Academia Brasileira de Letras, para a cadeira 25.

7 Jorge Amado (1912-2001) foi um escritor brasileiro nascido em Itabuna, Bahia. O romance "Gabriela Cravo e Canela" recebeu os prêmios Jabuti e Machado de Assis. Foi Membro da Academia Brasileira de Letra, ocupando a cadeira de $\mathrm{n}^{\circ}$ 23. Iniciou sua carreira de escritor com obras de cunho regionalista e de denúncia social. Passou por várias fases até chegar na fase voltada para crônica de costumes. Politicamente comprometido com ideias socialistas foi preso duas vezes, uma em 1936 e outra em 1937. Exilado, viveu em Buenos Aires, França, Praga e em vários outros países com democracias populares. Voltou para o Brasil em 1952. Entre suas obras adaptadas para a televisão, cinema e teatro estão "Dona Flor e Seus Dois Maridos", "Gabriela Cravo e Canela", "Tenda dos Milagres" e "Tieta do Agreste".

8 Alfredo de Freitas Dias Gomes (1922-1999) foi um escritor brasileiro nascido em Salvador. Foi autor de novelas que fizeram grande sucesso na televisão, entre elas "O Bem Amado" "Roque Santeiro" e "Saramandaia". A peça "O Pagador de Promessas", escrita nos anos 60 foi adaptada para o cinema e para a TV.
} 


\section{A influência dos potentados locais na estrutura administrativa brasileira}

como objetivo transformarem favores aos eleitores em votos, prometendo promessas futuras aos votantes (PANG, 1979, p. 59).

Na Primeira República, a presença membros da Igreja na política já ocorria. A afeição popular a padres envolvidos na política, foi devido a Igreja ser uma representação de orientação moral a sociedade daquele período. Um exemplo de influência de um religioso na política da Primeira República, ocorreu no Vale do Cariri, interior do Ceará, com a figura do padra Cícero Romão Batista, o Padre Cícero ${ }^{9}$. O Vale do Cariri se tornou um local central no catolicismo brasileiro. $\mathrm{O}$ fanatismo religioso naquela região proporcionou a criação de alianças coronelistas no interior do nordeste brasileiro. Após o anuncio do milagre operado pele Padre Cícero ele se transformou em figura notável no Cariri.

A população de sua comunidade aumentou, provendo mão-de-obra barata para a economia local, e em breve Cícero tornou-se um bem-sucedido empresário de diversos investimentos no Vale do Cariri. Os coronéis locais uniram-se ao Padre Cícero, porque ele atraía trabalho e fornecia um mercado para as principais atividades econômicas. (PANG, 1979, p. 54).

Padre Cícero foi o principal exemplo de coronel padre, pois houve uma união dos coronéis a sua figura, tornando o Padre Cícero o coronel dos coronéis no sertão nordestino até sua morte em 1934. Atividades econômicas de outros Estado circulavam em torno de Juazeiro do Norte, localidade de Cícero. Houve outros exemplos de religiosos coronéis como: Monsenhor Ermílio Leão, de Lavras Diamantinas (Bahia), e o Monsenhor Walfredo Leal ${ }^{10}$, de Areia (Paraíba). Ambos galgaram cargos na esfera estadual como na federal, porém nenhum com maior prestígio e influência que Padre Cícero.

O coronelismo para Vitor Nunes Leal teria fim na medida em que a sociedade se urbanizasse, pois, o isolamento na concepção do autor facilitava à ausência do poder público. Com o sufrágio os votos dos trabalhadores ganharam importância. Devido a desajustada estrutura econômica e social brasileira, se determinou como tarefa do poder público ensinar a nova massa eleitoral a sua respectiva função política. Entretanto, o poder público ainda era deficiente, recorrendo assim ao diminuto poder privado, fundando assim o fenômeno do "coronelismo". Conforme Victor Nunes Leal desprende em sua obra, a Revolução de 1930 foi início da derrocada do coronelismo, pois serviu para transpor o plano político e a promulgação do Código eleitoral de 1932, ferramenta essa que abalaria o sistema. Quando a maioria dos votos se encontrasse nos grandes centros urbanos, o fenômeno do coronelismo para Leal estaria acabado.

A socióloga Maria Isaura Pereira de Queiroz (1975) diferentemente de Vitor Nunes Leal, argumentou que o coronelismo não é estritamente um fenômeno político. Para a autora o coronelismo tratou-se de um

\footnotetext{
${ }^{9}$ Padre Cícero (1884-1934) nasceu no dia 24 de março, na cidade do Crato, Ceará. Filho de Joaquim Romão Batista, comerciante, e Joaquina Vicência Romana. Foi ordenado padre em Fortaleza no ano de 1870. Realizou um trabalho pastoral, com pregações e visitas domiciliares. Conquistou a simpatia dos católicos. Foi punido pelo Vaticano, com a suspensão da ordem. Foi acusado de manipulação da crença popular. Exerceu cargos políticos em Juazeiro do Norte. Em 1977, foi canonizado pela Igreja Católica Apostólica Brasileira. Hoje Juazeiro é ponto de peregrinação de seus fiéis.

${ }_{10}$ Monsenhor Walfrido Leal nascido na cidade de Areia, no Brejo Paraibano. Devido ao cargo religioso, o Monsenhor Walfredo Leal teve forte influência no Brejo e Litoral da Paraíba, chegando a ser eleito deputado estadual (deputado constituinte estadual) em 1892. Em seguida foi eleito Vice-presidente de estado, nos períodos 1893, 1894, 1896 chegando a governar o estado em várias ocasiões. Foi eleito Deputado federal em 1901. No período de 1905 a 1908, exerceu o cargo de Presidente (hoje denominado "Governador") do estado da Paraíba.
} 


\section{A influência dos potentados locais na estrutura administrativa brasileira}

fenômeno mais complexo. A origem do coronelismo ocorreu pela associação de grupos de parentela. O entendimento do termo "parentela" como: "um grupo de parentesco de sangue formado por várias famílias nucleares e algumas famílias grandes (isto é, que ultrapassam, o grupo pai, mãe filhos), vivendo cada qual em sua moradia, regra geral economicamente independentes) "(QUEIROZ, 1975, p. 165). Portanto a estrutura econômica do país foi estabelecida sobre esses grupos de parentela e não pela estrutura fundiária, ressaltando a visão sociológica da autora. Com a ampliação da base eleitoral, esse sistema de parentela foi ampliado, pois o voto se tornou um bem de troca, propiciando vantagens econômicas tanto para os chefes como para os demais membros da parentela. As parentelas além de serem um grupo econômico independentes, também seriam um grupo político. Por meio da solidariedade interna, a lealdade entre os membros com os chefes seria mantida.

Outro ponto de destaque na análise de Maria Isaura Pereira de Queiroz é a posse dos bens de fortuna. Esses bens de fortuna seria a capacidade do coronel de garantir os favores, na medida em que o coronel tem essa maior capacidade, maior será o eleitorado controlado pelo chefe. As parentelas têm a competência de assegurar a durabilidade de suas alianças mesmo quando ocorrem mudanças inesperadas, tanto de caráter ideológico, econômico e político. As parentelas se reagrupam com eficiência ao serem submetidas às mudanças, garantindo a sua continuidade de mando.

O término do coronelismo para autora não foi devido a um único fator, mais de vários fatores englobados sendo eles a urbanização, o crescimento demográfico e a industrialização. Não existe uma data definida que marque o fim do fenômeno coronelista marcar, pois analisando sociologicamente, o impacto das mudanças impostas pela modernidade se diferenciou de região para região.

\section{CONSIDERAÇÕES FINAIS}

O debate referente ao poder privado e o poder público sempre foi referido na história brasileira. A influência de líderes locais na vida e no cotidiano das pessoas, foi diminuindo gradativamente na medida em que a figura pública do Estado se consolidava no Brasil. Essa disputa foi marcada por nuances. Em determinados períodos, tivemos um poder privado poderoso, com os potentados locais fortalecidos, contra um poder público incapaz de penetrar na rotina da população. A análise das atribuições das Câmaras Municipais, ao longo do período colonial, Império e na República, nos revela como a influência de potentados locais foi diminuindo gradativamente. No período colonial, as Câmaras Municipais gozavam de certa autonomia, mantendo atribuições em praticamente todos os setores, destacando as competências judiciárias, financeiras e militares.

Após a Independência, houve a criação de instituições para desenvolvimento do aparelho administrativo e fortalecimento estatal. $\mathrm{O}$ poder público modificou-se, havendo uma centralização administrativa e consequentemente uma consolidação da burocracia brasileira.

O último resquício do exorbitante poder privado no Brasil se deu por meio do coronelismo. Apesar de ter ultrapassado os limites da Primeira República, o fenômeno teve o seu auge nesse período. Nesse enredo o poder privado representado pelos coronéis, se entrelaçou com o poder público, procurando assim, manter determinados benefícios. A política dos "coronéis" revela o enfraquecimento do poder privado no cenário 


\section{A influência dos potentados locais na estrutura administrativa brasileira}

público brasileiro, por conta disso, o coronelismo foi uma das últimas apropriações que o poder privado fez do espaço público no país.

\section{FONTES HISTÓRICAS}

BRASIL- Lei de 1\%10/1828 - Criando em cada Cidade e Vila do Império Câmaras Municipais. In: CONSTITIÇÕES DO BRASIL. Vol. I. Brasília: Senado Federal, 1986.

BRASIL- Decreto $\mathrm{n}^{\circ}$ 842, de 19 de Setembro de 1855. In. Coleção das Leis do Brazil. Disponível no site da Câmara dos Deputados: http://www2.camara.leg.br/legin/fed/decret/1824-1899/decreto-842-19-setembro1855-558297publicacaooriginal-79444-pl.html) Acesso em 21/02/2018.

BRASIL - Decreto de 24 de fevereiro de 1932. Código Eleitoral. Biblioteca da Câmara dos Deputados. Brasília DF. Disponivel http://www2.camara.leg.br/legin/fed/decret/1930-1939/decreto-21076-24-fevereiro1932-507583-publicacaooriginal-1-pe.html Acesso em 21/02/2018.

\section{REFERÊNCIAS BIBLIOGRÁFICAS}

CARVALHO, José M. Mandonismo, Coronelismo, Clientelismo: Uma discussão conceitual. In: Scielo, v 40, n. 2. Rio de Janeiro, 1997. Disponível em: <http://www.scielo.br/scielo.php?script=sci_arttext\&pid=S0011-

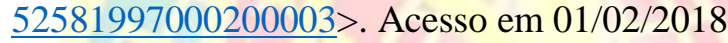

DOLHNIKOFF, Miriam. O pacto imperial: origens do federalismo no Brasil do século XIX. São Paulo: Globo, 2005, p. 330.

DUARTE, Nestor. A ordem privada e a organização nacional: contribuição à sociologia política brasileira. São Paulo: Companhia editora nacional, 1939, p. 242.

FAORO, Raymundo. Os donos do poder: formação do patronato político brasileiro. São Paulo: Ed Globo, 2000, 2v.

FREYRE, Gilberto. Casa-grande \& Senzala: formação da família brasileira sob regime da economia patriarcal. São Paulo: Global, 2006, p. 727.

GOUVÊA, Maria de Fátima Silva. O Império das províncias: Rio de Janeiro, 1822-1889. Rio de Janeiro: Civilização Brasileira, 2008, p. 362.

HOLANDA, Sergio Buarque de. Raízes do Brasil. São Paulo: Companhia das Letras, 1999, p. 220.

História Geral da Civilização Brasileira: o Brasil monárquico. Tomo II. Vol. I. $3^{\text {a }}$ ed. SP: Difusão Europeia do Livro, 1970, 5v.

JANOTTI, Maria de Lourdes Monaco. O Coronelismo: uma política de compromissos. São Paulo. Brasiliense, 1992, p. 88.

LEAL, Vitor Nunes. Coronelismo, enxada e voto: o município e o regime representativo, no Brasil. São Paulo. Alfa Omêga, 1975, p. 440.

QUEIROZ, Maria Isaura Pereira. O mandonismo local na vida política brasileira. São Paulo: Instituto de Estudos Brasileiros/USP, 1976, p. 230.

PANG, Eul -Soo, Coronelismo e oligarquias 1889-1934: a Bahia na primeira República brasileira. Rio de Janeiro: Civilização Brasileira, 1979, p. 269. 
PRADO JÚNIOR, Caio. Formação do Brasil contemporâneo. 14ed. São Paulo: Brasiliense, 1997, p. 390.

SCHWARTZMAN, Simon. Bases do autoritarismo brasileiro. Rio de Janeiro:Campus, 1982, p. 163.

SILVA, Maria B. Nizza da (coord.). Nova História da Expansão Portuguesa. In: SILVA, Maria B. Nizza. Império luso-brasileiro, 1750-1822. Vol. VIII. Lisboa: Editorial Estampa, 1986.

SOUZA, Juliana Teixeira. As câmaras municipais do Rio Grande do Norte nos anos 1830. In: ANAIS DO XXVI SIMPÓSIO NACIONAL DE HISTÓRIA, 2011, p. 1-14.

URICOECHEA, Fernando. O Minotauro Imperial: a burocratização do Estado patrimonial brasileiro no século XIX. Rio de Janeiro: Editora Difel, 1978, p. 332.

VELLASCO, Ivan de Andrade. Clientelismo, ordem privada e Estado no Brasil oitocentista:notas para um debate. In: CARVALHO, José Murilo, PEREIRA, Lúcia Maria Bastos (Orgs). Repensando o Brasil de Oitocentos: cidadania, política e liberdade. Rio de Janeiro: Civilização brasileira, 2009, p. 597.

VIANA, Oliveira. Instituições políticas brasileiras, São Paulo: J. Olympio, 1949, 2v.

Populações meridionais do Brasil, Brasília: Câmara dos Deputados, 1982, p. 748.

VILAÇA, Marcos Vinicios. Coronel, coronéis. Brasília. Ed Universidade de Brasília, 1978, p. 225.

Texto recebido em: 04/08/2019

Texto aprovado em: 17/11/2020 